\title{
REVEALING THE MYSTERY OF DEATH IN ADAT: A Factual Study of Sudden Death in Kedang
}

\author{
Rofinus Pati \\ Center for Religious and Cross-cultural Studies \\ of Gadjah Mada University \\ profinus@ymail.com \\ Samsul Maarif \\ Center for Religious and Cross-cultural Studies \\ of Gadjah Mada University \\ anchu75@yahoo.com
}

\begin{abstract}
This paper discusses the persisting Kedangese "indigenous religion" of Lembata. It begins with the discussion of a case of sudden death through which responses of the Kedangese are analyzed. Responses of Kedangese to the case of sudden death consist of ritual, consultation with ancestors, and animal sacrifice. The three kinds of responses show the characteristics of Kedangese worldview. Their worldview characterizes "inter-subjective" cosmology, an understanding that "subject" is not limited to human beings, but extends to non-human beings. Relations between the two are then "inter-subjective", as opposed to "subject-object" relations. This paper finally argues that "inter-subjective" cosmology characterizes Kedangese indigenous religion, different from world religions.
\end{abstract}

Keywords: Mystery of Death, Worldview, Intersubjetive

\section{INTRODUCTION}

This writing begins with the utterance of an illiterate father named Basirun Hamzah as follows: "If hospitals have sophisticated diagnosis facilities and excellent doctors and nurses, why must many of patients who come and visit the hospitals die? Even, many of those are still young and productive patients? Hospitals have bunch limitations to solve problems. Adat can present its own answers for those problems". As a father in remote area in Lembata Island, Hamzah was not satisfied when listening to the elaboration of the doctors regarding the dead patients that "the disease is already very serious or terminal" or "the patient is too late to come to the hospital". For him, all the sick people who stay in the hospital are in hope of recovery, not death. That many people spend plenty of money paying the bill of hospitals, it is not without any 
intention. Nevertheless, the way and place in which a man dies is absolutely uncertain. The certainty is absolutely that man must die. Mors certa, hora mortis incerta (death is certain, the hour of death is uncertain). But why must a man accept his own death in a sudden situation? Does this only deal with one's own carelessness? Is it just merely accident?

First of all, this article presents a fact of sudden death of Timoteus Hobong in Kupang. Even though Hobong lived in Kupang, his origin was from Mampir village, sub district of Buyasuri, Kedang. After that, the way in which Kedangese people unveil the mystery of death in an indigenous ritual (consulting the ancestral spirits) is presented along with references to opinions of some scholars who willingly get involved in researches on indigenous society. A simple analysis in this article is also offered regarding to the indigenous position, particularly in dealing with death. A conclusion will close this short writing.

Death and dying is an intersting issue as apart of religious and cultutal studies. The studies on the sudden detah of the of Timoteus Hobong in Kupang is an important work as death and dying is an important aspect in human life in which people pay a great attention on the issue. All groups of people living in this planet have given their important and significant attention in the issue of death and dying. The work by Sumarman Djar'ie and Zaenuddin Prasojo (2015) is an example of how people who belong to a certain group in West Kalimantan society pay a serious and significant attention on death and the rituals following the death. However, I provive the analisys of the sudden death case happening in Kupang for the important attention of academic work to the issue of death and dying for human life.

\section{A SUDDEN DEATH OF TIMOTEUS HOBONG}

For Kedangese people, a sudden death which strikes a person is certainly not a good death (mate dien), but a bad death (mate daten). In Kedangese cosmology, such a death is expressed as "the greedy mice that suddenly eats the ear of fresh corn" or it is perceived as "the storm in rainy season which suddenly destroys the plants" (Tiu Keteq, Waraq Rapu). In an analogy of a tree, the Kedangese call the sudden death as "the sudden falling twig on to the ground" (Limaq Hepuq, Lapan Balaq).

Such above expressions are due to Hobong's death which was not normal. A normal death in Kedangese perspective has to start with illness in a rather long period, family's members should take care of him, his close friends and relatives should make a visit to him. When the terminal illness is finally 
impossible to recover and the patient passes away, the family's members are pleased on account of their services to him until death. There is a sufficient time for them to assist the patient and deliver the last honor to him. Therefore, the sudden death as undergone by Hobong rised up something not normal and must be traditionally searched for the reasons.

Hobong was a teacher at Junior High School of Sint Gregorius, Buraen, sub district of Amarasi, Kupang. He suddenly passed away on June, 28, 2015. He did not ever have any medical record of heart attack. The death quickly turned him off when he took a nap after lunch. Medically speaking, many people concluded that he had a heart attack. Some others assumed that he was poisoned by his own wife but this was not provable since the saliva did not come out of the mouth. He and his wife did not get involved in any kinds of dispute. Daily relations with the neighbors had also been harmonious during his life.

His families, friends and relatives in Lembata decided to perform a customary ritual to search for and find out the reasons of his death. An indigenous priest whose charisma was acknowledged by the whole or many people was invited. This indigenous priest was believed to have a capability to tap into the 'world' of the death and link it with the living families, friends and relatives. The priest became the medium through which the 'two worlds' were able to encounter and overcome the unexpected situations.

\section{RITUAL OF “KEU RAPEQ” OR “TE'ELOTEQUA”.}

The ritual of "Keu Rapeq" or "Te'el Oteq Ua" began with the family's intention or initiative of Hobong to customarily know the causal factors of the unexpected death. To gain the cause of his death, Kedangese people usually use the things through which they are able to analyze the causes of death. Those things must be the properties of the dead, although his corpse is already buried. A piece of Hobong's shirt was to offer to the priest. If not, a sheet of his hair was to cut down for this purpose. This also included some pieces of 'sarongs' or dress he used to put on. After that, the traditional priest privately conducted his service based on traditional procedures. First of all, the priest was to sleep on the things of the dead for one or couples of nights. Secondly, he received symbols or pieces of facts transmitted from the dead side. Thirdly, the priest informed the results of his communication with the dead to the living families. Fourthly, he consulted the opinion or considerations of the ancestors to certify one of the symbols or pieces of facts as the main cause. To certify it, the priest attuned to the direction of rooster's leg. Sometimes the priest used the egg in which the egg would automatically break in the palm of the priest when uttering the 
right or proper cause. The automatic break of the egg justified the cause.

In this case of Hobong, the priest received those gifts and put them beneath the pillow. At night, the indigenous priest slept and put his head on the pillow. In the middle of the night, Hobong came in the vision or dream of the priest and Hobong explained why he underwent the unexpected death. Sometimes one or two nights are not sufficient for the priest to catch the trans-mission of information from the 'other' world.

Nevertheless, the reasons of death were not directly informed but those reasons were transferred in symbols or pieces of facts. Accordingly, the indicators (symbols and pieces of facts) should be analyzed again by collaborating or working together with the ancestral spirits through the medium of animals (roosters). This was intended to get the certain causal factors regarding the 'bad' death.

After spending two nights of collecting the info from the world of the dead, the indigenous priest waited for the families to come (on August, 8, 2015) and got the results. There were three symbols or pieces of facts in the vision of the priest regarding Hobong's death. They were (1) in his dream and vision, the priest saw a half-naked woman. (2) The priest saw the dead (Hobong) appearing to him with a stick of rattan in his right hand. Hobong then broke the rattan into two. He took a half of the rattan to his realm and left the other half to the priest with a particular message that the rattan was for his elder brother: Stefanus. (3) In his vision, the priest saw a garden or a land in the time of wet season. A man entered the garden or land and began planting corns. Not too long after the first man went, the other man arrived and took over the garden to occupy.

\section{CONSULTING THE ANCESTORS}

To properly interpret the symbols or pieces of facts above, the priest asked for indicator and opinion of the ancestors to certify the cause of Hobong's death. The indicator was apparently witnessed on the right legs of the roosters after being throttled. The roosters were primarily 'consecrated' by the priest in a specific chanting with hope that these animals became the drain of opinion or will of the ancestors. Having been throttled, if the right leg of the rooster was in front of the left one, it would indicate the ancestors agree with the interpretation proposed by the participants. Conversely, if the left leg of the rooster was in front of the right one, it would mean the ancestors disagree. If both of the legs were not in such regular positions, it would mean they truly disagree. In this attempt, all the roosters or hens throttled by the traditional priest might 
show the irregular or unexpected positions of the legs. The same other animals should be prepared again to consult the ancestors until they agree.

Each of those roosters represents one interpretation and the legs of the roosters become the indicator whether the interpretation is right or wrong. In the vision of the indigenous priest that a woman appeared to be half-naked, that suggested that a man in the family should have committed sexual intercourse with a woman, but punishment based on their customary law was not yet applied. When confirmed to the members, they confessed that it was correct. Morally, Kedangese people believe that amoral actions would bring about grave risk of death because the norms of adat are stronger than the norms of religions. People can explicitly argue that religious norms punish people after people die in the hereafter, but customary norms punish people during living until dying.

$===$

Regarding the second cause in which the priest in his vision saw Hobong coming and holding a stick of rattan in his hand, then he broke it and left a half of it for his elder brother Stefanus and brought the other half to his realm. In this case, the throttled-rooster's right leg sustains the interpretation that Stefanus was involved in a familial dispute and wanted to depart or separate from the other family's members and stay or live alone. Rattan symbolized or was a tool of punishment which contributed to Hobong's death due to familial conflicts. A half rattan left behind for Stefanus signals that he himself would die in a short coming future if he did not seriously repent and changed his whole life.

The third vision of the priest was that he saw a garden or land. A man firstly came to occupy the place. After that, the other, in turn, came to do the same. The rooster's right leg affirmed the interpretation of the participants that the dispute, hatred and anger in competing to occupy the inherited land had already become a grave cause of Hobong's death. Kedangese people believe that land or soil is not only the main source of life of the farmers but also the material from which all human beings derive. Consequently, the land or soil must be respected or honored. Competition to win the land or soil does not show the respect towards it so that it gets angry and becomes the hidden strength or power to destroy Hobong's life on this earth.

\section{SACRIFICE OF ANIMALS}

Sacrifice of animals [roosters] culminates in a communal meal. Before the meal, the ancestral spirits are firstly fed by the priest. The site of the meal for 
ancestors is placed on a small stone or leaf of a tree at the western direction of sunset. It is assumed that the meal will go with the rolling sun to the west and reach the ancestors there. They believe that they live in two contrast 'world'. When they are in the day, the ancestors are in the night. They take rice on a plate, but the ancestors on a stone or leaf of tree, the meat for ancestors consists of the end of wings, mouths, claws, and others which are commonly believed that they will accept the best.

The logic of sacrifice is based on the view that blood sacrifice is one of several ways to offer something to a deity or ancestral spirits. A sacrifice may also be an event that foregrounds a certain idea of social relation. In sacrifice, humans give themselves through the substitution of an animal in order to pay the debt of life. This is a mutual "taking and giving" process in which each party plays the essential role for the good of all beings. Besides, the sacrifice is the prime activity that allows people to fulfill the aspiration of ancestral spirits. The aspiration of goodness which should be put into practice and the aspiration of the not-goodness which should be avoided in the frame of inter-subjective relations.

Communal feast ornamented by the baked meat in Kedangese view includes some aims such as a thanksgiving to the ancestors for assistance in finding out the causal factors of Hobong's death; yielding for protection of the ancestors from the misfortune or sudden death in families for now and in the future; intention of all the participants to reconcile and preserve the harmony through the sacrifice of animals and this requires a total or radical change in attitudes of daily lives.

\section{VIEWING THE WORLDVIEW OF KEDANGESE PEOPLE}

The world view of the Kedangese needs to be taken into consideration in order to capture and express their local religion. Each community has particular characters relating to its attitudes. As accentuated by Maarif $(2016,47)$ and Redfield $(1952,30)$, a worldview is linked with how a 'world' in the eyes of those who have different perspectives. This is in accordance with the diverse characters owned by "the other being" [sang liyan] and the 'self'. In brief, it absolutely relates to the idea of cosmos. A human being, when asking about himself of who he is, where he originates and where he will go, he definitively refers to the cosmos. In spite of the self, it correlates with others of who else be with me, who shares with me, to what extent a relation that "I" and "the other" should have, etc. All these components collaborate for the balance of cosmos. "Keu Rapeq" or "Téel Oteq Ua" is also a practice of indigenous religion in 
Kedang, eastern Lembata. The Kedangese people, in their own ways, attempt to cope with the mystery of death (concretely in the death of Hobong). In this context, they do not need to blindly refer to the world religious teaching or medical paradigm. They are not in the position of judgment whether or not their tradition is more appropriate. At least, they have their inherited practice of overcoming the mystery of death as the unavoidable existential fact. They want to live with "the other" (non-human being) in a mutual contribution. The Kedangese are totally aware of their presence with the ancestral spirits and with the garden / land which continuously grants them their daily bread.

In spite of that, the Kedangese also have an indigenous paradigm (Maarif, 2016, 49) which accentuates the intersubjective relations. The ancestral spirits, the spirit of Hobong who comes in the vision of the priest, the disputed land or garden are equally located in the position of "subject-subject". They are in inter-dependence and inter un-separable correlation. The non-human beings/ creatures (in this exposition, namely. ancestral spirits, spirit of Hobong, the land) have desire, want, and power as what humans do. Their response to the humans' world may be in the human control or prediction, yet sometimes it is out of it (Maarif, 2016, 50 and Hallowell 1960/2000, 168).

Subject-subject relation is also apparently witnessed in the Kedangese attempt to unveil the death of Hobong. Ancestral spirits who are believed present in a partly naked woman in the first vision of the priest assist Hobong's family to promptly interpret the intention behind it. A stick of rattan held by Hobong in the second vision enables the living family to connect it with their behaviors in daily life of family's members. Furthermore, the disputed garden or land in the third vision also has inter-subjective relation with human beings. The land is treated as a subject. In the hamlet, almost each family has a granary in which all the harvest of corn is kept until the subsequent rainy season arrives. When it arrives, the seed of corn to plant is taken out of the granary and people sow or throw them down everywhere on the ground. All people do this in the house yard as the memory of land which gave them good harvest last year while hoping the same result in the rainy season. Like humans, land also has power and it is totally perceived that the land is able to give certain response to those who dispute or compete with each other for taking over it. That is why, the land (which is regarded as the origins of human beings) suddenly snatched the life of Hobong away.

Subjective relation also occurs within the communication between the dead Hobong and his living family. This contact is bridged by the priest. Hobong is a subject coming in vision via the means of his shirt and sheet of hair under pillow. This also means that Hobong is dead but still alive in the heart, in the shirt and hair as memories. The living families are able to meet again with 
Hobong through the priest in order to manage and overcome their common problems for the genuine harmony.

\section{INTER-SUBJECTIVE RELATIONS IN COMMUNAL MEAL}

As previously highlighted, ancestral spirits are totally considered as subjects who are worthily treated. The ancestral spirits are honored and sincerely granted for the first occasion to consume the meal. In communal meal, it points out to a fact that they are not easily separable and they ultimately get involved in a mutual relation and contribution.

Through a sacrifice of animals, ancestral spirits as 'subjects' are invited to symbolically eat together and renew the relation. In human beings side, they hope of ancestral protection in the coming days. Both the sacrifice of animals and communal meal affirm a main point that Kedangese people (i.e. after the death of Hobong) intend to get rid of present or future evil by offering the animals and consume their meat together with the ancestral spirits (cfr Pritchard 1956: 197-230). Here is a conception of "take and give" promoted by each party. From the Hobong's family, they give the sacrifice of animals to the ancestral spirits and yield for protection and safety. Conversely, the spirits of ancestors receive or take the sacrifice and grant protection and safety to the family.

Furthermore, sacrifice itself means that each party should have a good will to attain the imagined union laying above all the personal interests. Treating all states or beings of the world as 'subjects' enable each party to confess that, in the world of "becoming", there is a common destination to gain, a common ground to live on, and finally a common reason love one another.

Briefly speaking, communal meal indicates a collegial atmosphere of those who partake in it. In the context of Hobong death, communal meal symbolizes that the persons are sisters and brothers. They are aware that they can do wrong as humans. They can forgive and forget the mistakes of their fellow humans. Each of them should erase all the anger, hatred or revenge in the heart to recraft the cosmological balance (harmony). That is because the family realizes that when the harmony disappears (in the loss of Hobong life), they presently need the harmony indeed.

\section{CONCLUSION}

Then, how about the pessimism of Basirun Hamzah in the beginning of this writing towards the capability of hospitals to save the souls of the patients? It is not possible to chase away all the doctors and nurses and shut the hospitals. Similarly, it is impossible to stop all the religious leaders from speaking of 
"heaven" and "hell". Facing the sophisticated medical technological facilities which are not capable in saving human lives, Hamzah has his own reason to hold his adat tradition. Facing also the religious teachings which proclaim that the salvation is promised for those who bear the burdens of life until death, Hamzah is strictly triggered to tap into his adat. This is also due to the fact that the salvation offered in the world religions is in, and for the future. Conversely, Kedangese people accept the death of humans as the problem of "now and here" which they should search for the answers that hopefully can satisfy them. The loss of one member in a 'bad' death is considered annoying or bothering the balance of society (harmony). That is why, Kedangese people, in the conception of intersubjective relation, perform the ritual of "Keu Rapeq" or "Téel Oteq Ua" in order to pass over all kind of hindrance and sustainably pursue and preserve the sustainable harmony or balance.

In front of the mystery of death, Kedangese people want to reveal in their own local strategy. They are curious to immediately know the answers, because they live out their lives for "now and here", not for "the future and there". And they also live in unity with cosmos, not in the "surga" (future heaven). On the one hand, they do not live for a future promise as guaranteed in Abrahamic religions. And, in the other, they are not fully satisfied with the powerless sophisticated hospitals which fail in recovering the young and productive bodies of sick people. Nevertheless, they do not have the position to underestimate or judge other teachings as right or wrong. They just search for their own solution to comprehend the meaning of life.

In, and through the ritual of "Keu Rapeq" or "Te'el Oteq Ua", Kedangese people show their local wisdom and alternative of solving the mystery of death in inter-subjective relations among fellow-humans and "non-human beings" such as spirit or soul of Hobong, spirits of ancestors and inherited garden / land. All these beings of the world have a common and mutual responsibility and reciprocity to contribute to the balance of cosmos. ${ }^{* * *}$

\section{REFERENCES}

Ammerman, N. T. (2007). Everyday Religion: Observing Modern Religious Lives. Oxford: Oxford University Press.

Djar'ie, S. M. \& Zaenuddin H. Prasojo, (2015). "Religion, Culture and Local Wisdom in the Death Ritual of Pontianak Malay Society." in Journal of Al Albab.

Eliade, M. (2000). "Kronologi Studi Agama sebagai Disiplin Ilmu." in Ahmad 
N. Permata (ed.). Metodologi Studi Ilmu Agama. Yogyakarta: Pustaka Pelajar.

Maarif, S. (2016). "Kajian Kritis Agama Lokal.” in Samsul Maarif (ed.), Studi Agama di Indonesia, Refleksi Pengalaman. Yogyakarta : CRCS.

Redfield, R. (1952). “The Primitive World View." in Proceedings of the American Philosophical Society. p: 30-36.

Subagya, R. (1981). Agama Asli di Indonesia. Jakarta: Sinar Harapan dan Yayasan Cipta Loka Caraka. 